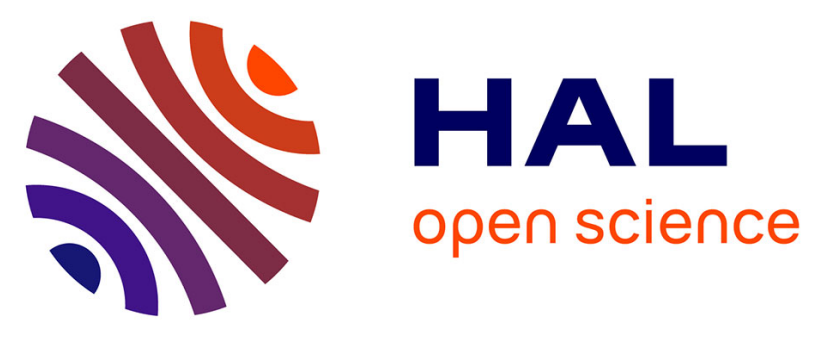

\title{
Clonal replacement and expansion among invasive meningococcal isolates of serogroup $\mathrm{W}$ in France
}

Eva Hong, Anne-Sophie Barret, Aude Terrade, Mélanie Denizon, Denise Antona, Myriam Aouiti-Trabelsi, Ala-Eddine Deghmane, Isabelle Parent Du Châtelet, Daniel Levy-Bruhl, Muhamed-Kheir Taha

\section{To cite this version:}

Eva Hong, Anne-Sophie Barret, Aude Terrade, Mélanie Denizon, Denise Antona, et al.. Clonal replacement and expansion among invasive meningococcal isolates of serogroup $\mathrm{W}$ in France. Journal of Infection, 2018, 76 (2), pp.149-158. 10.1016/j.jinf.2017.10.015 . pasteur-01950885

\section{HAL Id: pasteur-01950885}

\section{https://hal-pasteur.archives-ouvertes.fr/pasteur-01950885}

Submitted on 30 Mar 2019

HAL is a multi-disciplinary open access archive for the deposit and dissemination of scientific research documents, whether they are published or not. The documents may come from teaching and research institutions in France or abroad, or from public or private research centers.
L'archive ouverte pluridisciplinaire HAL, est destinée au dépôt et à la diffusion de documents scientifiques de niveau recherche, publiés ou non, émanant des établissements d'enseignement et de recherche français ou étrangers, des laboratoires publics ou privés.

\section{(1) $(1) \Theta$}

Distributed under a Creative Commons Attribution - NonCommercial - NoDerivatives 44.0 


\section{Clonal replacement and expansion among invasive meningococcal isolates of serogroup W}

in France

Eva Hong $^{\mathrm{a}, \dagger}$, Anne-Sophie Barret ${ }^{\mathrm{b}, \dagger}$, Aude Terrade ${ }^{\mathrm{a}}$, Mélanie Denizon ${ }^{\mathrm{a}}$, Denise Antona ${ }^{\mathrm{b}}$, Myriam Aouiti-Trabelsi ${ }^{\mathrm{a}}$, Ala-Eddine Deghmane ${ }^{\mathrm{a}}$, Isabelle Parent du Châtelet ${ }^{\mathrm{b}}$, Daniel Levy-Bruhl ${ }^{\mathrm{b}}$, Muhamed-Kheir Taha ${ }^{\mathrm{a}, *}$

${ }^{a}$ Institut Pasteur, National Reference Centre for Meningococci and Invasive Bacterial Infections Unit. F-75724, Paris, France

${ }^{\mathrm{b}}$ Sante publique France, French National Public Health Agency, F-94415, Saint-Maurice, France.

${ }^{\dagger}$ These authors contributed equally to this work.

*Corresponding author Muhamed-Kheir Taha mktaha@pasteur.fr Tel +3314568 8438 


\section{Abstract}

\section{Background}

3 Neisseria meningitidis group W (NmW) belonging to the clonal complex ST-11 (NmW/cc11)

4 spread in Europe and in France in 2000 and declined thereafter. In France, invasive

5 meningococcal disease (IMD) due to NmW increased again in 2012 and thereafter since 2015.

6 Several sub-lineages of $\mathrm{NmW} / \mathrm{cc} 11$ are circulating worldwide with successive epidemic waves.

7 We aimed to describe recent epidemiological trends of $\mathrm{NmW}$ in France and to explore the

8 microbiological and epidemiological characteristics associated with different NmW/cc11 sub-

9 lineages.

\section{Methods}

11 The epidemiology of $\mathrm{NmW}$ was described based on data collected through mandatory

12 notification of IMD and strain typing data for culture-confirmed and PCR-confirmed cases for the

13 period 2000-2016. All culture-confirmed cases due to $\mathrm{NmW}$ from the period 2010-2016 were

14 characterized by whole genome sequencing (WGS). A detailed epidemiological analysis was

15 performed for culture-confirmed cases on the basis of WGS data.

\section{$16 \quad$ Findings}

17 During the period 2010-2016, genotyping was obtained for 148 cases including all the 132 18 culture-confirmed cases, among which 127 were matched with epidemiological data, and 16

19 PCR-confirmed cases (out of a total of 47 PCR-confirmed cases). An increase in IMD was

20 observed in 2012 and was linked to isolates belonging to the "Anglo-French-Hajj" sub-lineage.

21 These isolates have decreased significantly since 2013 and have been replaced by NmW/cc11

22 isolates related to the "South American - UK" sub-lineage which caused a marked increase in the

23 number of cases of $\mathrm{NmW}$ in 2016. In this sub-lineage, the "original UK strain" was first detected

24 in 2012 and increased thereafter, followed by the recently described "UK 2013-strain". Isolates 
25 related to the "South American-UK" sub-lineage represented 45\% of all NmW cultured isolates

26 from the whole period 2010-2016 but were the most frequent isolates in 2016, representing $76 \%$

27 of the total $\mathrm{NmW}$ typed isolates and $94 \%$ of the typed NmW/cc11 isolates. A changing pattern in

28 the epidemiology of $\mathrm{NmW}$ has been observed in 2015-2016 in relation to the spread of the "UK

29 2013-strain" with a sharp increase in the number of cases among persons aged 15 years and over

30 and a high case fatality rate (CFR). Among cases due to the "UK 2013-strain", 94\% of cases

31 were aged 15 years and over and the CFR was $28 \%$.

\section{Interpretation}

34 Our data suggest a recent clonal replacement among NmW/cc11 isolates with the expansion of 35 the "South American-UK" sub-lineage in France and particularly the "UK 2013-strain" which 36 was predominant in 2015 and 2016. A shift in the age-distribution of IMD due to NmW to older

37 ages and the high CFR are consistent with the expansion of a new virulent clone in a naive 38 population. These data may have an impact on tailoring vaccination strategies against NmW. 


\section{Highlights}

50 Neisseria meningitidis group W is currently increasing in Europe and in France.

51 Previous increases in France were linked to the Hajj and to travel to Africa.

52 Whole genome sequencing was used to characterise W isolates in France in 2010-2016.

53 The "UK 2013-strain" has recently expanded in adults aged 15 years and over.

54 A high case fatality rate was observed among cases caused by the "UK 2013-strain". 


\section{Introduction}

Invasive meningococcal disease (IMD) is caused by the Gram negative bacterium

75 Neisseria meningitidis (Nm) and mainly manifests as septicaemia and meningitis. This bacterium

76 is frequently hosted in the nasopharynx (1). Invasive isolates (responsible for IMD) are usually

77 capsulated while carriage isolates are frequently non-capsulated (2). The polysaccharide

78 composition of the capsule defines the serogroup. Twelve serogroups are currently described but

796 of them (A, B, C, Y, W and X) are responsible for almost all IMD worldwide with

80 high geographic variation $(3,4)$. Vaccines based on the capsular polysaccharides are available

81 against serogroups $\mathrm{A}, \mathrm{C}, \mathrm{Y}$ and $\mathrm{W}$ meningococci while protein-based vaccines target

82 serogroup B meningococci (5).

83 In France, routine vaccination with meningococcal C conjugate vaccines (MCCV) was

84 introduced into the immunization schedule in early 2010 for infants at 12 months of age and a

85 catch-up until 24-years-old (one dose of MCCV). Vaccination against meningococci ACWY and

86 against meningococci B are recommended for at risk subjects and outbreaks control (6).

87 The management of IMD requires both treatment of patients and prophylactic measures

88 among close contacts to avoid secondary spread. Surveillance is also a key element to

89 better tailor vaccination strategies. Indeed, IMD occurs as sporadic cases with occasional

90 outbreaks in Europe and North America while major epidemics periodically occur in Sub-

91 Saharan Africa (7). Meningococcal isolates showed high diversity with occasional global

92 spread of epidemic strains belonging to different serogroups (7). Serogroup W (NmW) isolates

93 have been detected since the late 70 s but historically caused a minor proportion of IMD

94 cases globally. In 2000, NmW underwent a first global spread among Hajj pilgrims and their

95 contacts (8). Subsequently NmW spread in the African Sub-Saharan meningitis belt and caused major outbreaks in Sub-Saharan 
96 countries at the beginning of the 2000s and in 2010 (9-11). During the 2000 decade, NmW

97 also emerged in the South America Cone and spread to the United Kingdom (UK) in 2009

98 (12-14). Tracking these isolates requires powerful typing methods such as multilocus

99 sequence typing (MLST) based originally on the sequence of 7 meningococcal genes. MLST

100 determines sequence types (ST) that can be clustered into clonal complexes (cc) (15). Several

101 clonal complexes have been identified but most $\mathrm{NmW}$ outbreak isolates belong to the

102 clonal complex cc11 (cc22 maintains a steady presence in many countries) $(7,12)$. However,

103 MLST may lack resolution to discriminate clones that can be resolved by whole genome

104 sequencing (WGS) (16). Core genome MLST (cgMLST) has already been used to describe the

105 the global spread of W/cc11 lineage in several countries over decades and allowed the

106 characterisation of distinct sub-lineages within W/cc11 isolates. In particular, it showed the

107 emergence of the "South American - UK" sub-lineage in UK which has been further

108 characterised in two distinct strains: the "original UK strain" which emerged in UK in 2009

109 and the "UK 2013-strain" which emerged in UK in 2013 (17).

110 In France, studying the characteristics of $\mathrm{NmW} / \mathrm{cc} 11$ is particularly interesting as various W/cc11

111 sub-lineages have been co-circulating in the country in addition to $\mathrm{NmW}$ isolates belonging to

112 other clonal complexes $(10,18,19)$. A thorough genetic analysis of $\mathrm{NmW}$ isolates combined with

113 epidemiological data on cases may unravel differential spread/virulence/replacement abilities.

114 We aimed to explore the characteristics of NmW IMD cases caused by these different lineages

115 and sub-lineages in France since 2010.

116

117

118

119 


\section{Surveillance of IMD in France}

122 The French surveillance system of IMD is based on the mandatory notification of IMD cases on

123 the basis of a standardized case definition. Cases are notified to the Regional Health Agencies

124 which implement local control measures. The notification forms are then sent to Santé publique

125 France, the French national public health agency, for data entry and analysis for the purpose of

126 epidemiological surveillance. IMD cases are notified on the basis of at least one of the following

127 criteria: isolation of $N$. meningitidis or detection of $N$. meningitidis nucleic acid by PCR (PCR

128 was introduced in 2002 in the case definition) from a normally sterile site (blood, cerebrospinal

129 fluid (CSF), other sterile sites or purpuric skin lesions) ; detection of Gram-negative stained

130 diplococci in CSF; purulent CSF associated with purpuric skin lesions or with the detection of

131 N. meningitidis antigens in blood, urine or CSF (antigen detection was not used anymore

132 after 2014); purpura fulminans (severe sepsis with extensive hemorrhagic and necrotic skin

133 lesions) (19). In addition, $N$. meningitidis isolates, as well as PCR positive samples are

134 sent to the National Reference Centre for Meningococci (NRCM) for confirmation and full

135 strain typing. Meningococcal groups are determined by agglutination of cultured isolates

136 using specific "in house" rabbit sera and by PCR for non-cultured confirmed cases (20).

137 Throughout the manuscript "group" will be used to refer to both serogroup and genogroup to

138 characterise cultured-confirmed and PCR-confirmed cases respectively. PCR confirmation and

139 typing techniques performed at the NRCM include PCR targeting N. meningitidis-specific

140 genes as well as capsular genes for serogroup determination (ctrA, sodC, $\operatorname{csa} B, \operatorname{cs} B, \operatorname{cs} C$,

$141 \quad \operatorname{cs} W, \operatorname{cs} Y$ and $\operatorname{csx} A)$.

142

\section{Genomic analysis}


143 The NRCM performs systematically MLST analysis on all IMD cases (cultured and PCR-

144 confirmed cases) since 2010 as previously described (18, 20, 21). Typing data are expressed as a

145 genetic formula: $G$ :P1.PorA-VR1,PorA-VR2:FetA :cc that define the group (G), the two

146 variable regions (VR1 and VR2) of the outer membrane protein PorA, and of one VR of the 147 protein FetA, as well as the cc.

148 Moreover, WGS is also performed systematically on all invasive cultured isolates since late 2015.

149 For this work we retrospectively performed WGS on all cultured NmW isolates since 2010.

150 Genomic DNA was extracted by using a Genomic-tip 20/G kit (QIAGEN, Valencia CA, USA).

151 Sequencing was performed by Illumina HiSeq 2000 sequencer (Illumina, San Diego, CA, USA)

152 and assembled as previously described (21). Sequences are available through the PubMLST

153 database which runs on the Bacterial Isolate Genome Sequence Database (BIGSdb) platform

154 (22). WGS data was analyzed using a "gene-by-gene" approach available through the PubMLST

155 Genome Comparator tool using N. meningitidis core genome v1.0 that includes 1605 core loci

156 (22). SplitsTree4 (version 4.13.1) was used to visualise the resulting distance matrices as

157 Neighbour-net networks (23). For the genomic analysis we included three reference strains

158 according to Lucidarme et al (24): one French isolate related to the "Anglo-French Hajj" sub-

159 lineage (ID31165), one isolate related to the "original UK strain" (ID20196) and one isolate

160 related to the "UK 2013-strain" (ID30167). The IDs of all these isolates are given in the

161 supplementary Table to allow retrieving of WGS sequence in FASTA formats.

\section{Study period}

164 Two periods were considered: (i) 2000-2016 for the description of the epidemiological trends of 165 NmW IMD and MLST and (ii) 2010-2016 for the whole genome analysis and the characteristics 166 of cases according to the different sub-lineages. 


\section{Data analysis}

168 Two databases were used in this study. The first one relates to IMD cases reported through

169 mandatory notification and includes clinical, epidemiological data as well as microbiological data

170 (technique for diagnosis and group identified by the local hospital or by the NRCM). The second

171 database includes data on all $\mathrm{NmW}$ invasive strains characterized by the NRCM. These two

172 databases are highly dependent but do not completely overlap. Cases in the database of the

173 NRCM included PCR since 1998 while PCR was added on the criteria of the mandatory

174 reporting in 2002. Data analysis was performed distinctly using these two databases except for

175 the analysis of characteristics of cases by lineages/sub-lineages for which the databases were 176 merged.

177 Epidemiological and clinical characteristics of cases were studied by groups (NmW versus other 178 groups) and by NmW lineages and sub-lineages identified by WGS. Proportions were compared 179 using Chi-square test or Fisher exact test using the threshold of p-value $<0.05$ as statistically

180 significant. Poisson regression was used to estimate the relative risk (RR) for death by group after 181 adjusting for age. Statistical analysis was performed using Stata version 12.1 software. 


\section{Results}

\section{Epidemiology of NmW IMD}

193 Between 2000 and 2016, the number of cases fluctuated in relation with the global spread of

$194 \mathrm{NmW}$ and multinational outbreaks (Fig.1). In 2000-2003, a first increase was described in 195 relation to the global Hajj-associated outbreak $(8,18)$. Then, from 2003 to 2011, there was a 196 marked decreasing trend and at the lowest level in 2009-2011, NmW caused around 10-15 cases

197 per year representing 2\% of all IMD cases (Fig. 1). In 2012, there was a transient increase in the 198 number of cases in relation to outbreaks in African Sub-Saharan countries. In 2015 and 2016, a 199 new upsurge was observed. In 2016, 45 cases were reported (incidence rate of 0.07 / 100000 200 inhabitants). $\mathrm{NmW}$ remained the least frequent group identified but the proportion of cases due to $201 \mathrm{NmW}$ increased compared to previous years. In 2016, of 506 IMD cases with known group, 52\% 202 of IMD belonged to group B, 26\% to group C, $12 \%$ to group Y and $9 \%$ to group W.

204 In 2015-2016, there were significant differences in characteristics of IMD cases according to the 205 strain group (Table 1). The proportion of cases in age groups above 15 years old was higher for 206 group W compared to group B and C cases. NmW IMD was associated with a higher CFR 207 (22.1\% vs $10.4 \%$ for other groups, $\mathrm{p}=0.002)$. After adjusting for age, the CFR was still greater 208 among group $\mathrm{W}$ cases than other groups $(\mathrm{RR}$ for death $=1.2$ [95\% IC 1.01-1.42]). In comparison 209 with group B and C cases, group W cases presented more frequently with septicemia and less

210 frequently with meningitis (Table 1). The proportion of cases with $\mathrm{Nm}$ isolated from synovial 211 fluid was greater among $\mathrm{NmW}$ cases.

\section{Molecular characteristics of $\mathbf{N m W}$ invasive meningococcal isolates}


214 During the period 2000-2016 the NRCM received samples for 527 cases of NmW IMD : 480

215 (91\%) cases were cultured-confirmed and 47 (9\%) were only PCR-confirmed (MLST performed

216 on PCR-confirmed cases since 2010). The annual distribution of cases is shown in Fig. 2. MLST

217 data were available for 366 cases (69\%) including all the cultured-confirmed cases since 2010

$218 \quad(\mathrm{n}=132)$ and 16 of the 47 cases that were only PCR-confirmed.

219 Among the 366 cases with MLST data, cc11 was the most frequent and caused 195 cases (53\%)

220 followed by cc22 with 128 cases (35\%) while other cc were responsible for 43 cases (12\%). The

221 cc11 isolates were responsible for the increase of NmW IMD observed at the beginning of the

222 2000s, in 2012 and in 2016 (Fig. 1 and Fig. 2). The number of NmW/cc11 cases was particularly

223 high in the years 2000, 2001 and 2016. Over all the study period, NmW/cc11 isolates showed the

224 same genotypic formula (W:P1.5,2:F1-1:cc11). NmW/cc22 isolates were more heterogeneous.

\section{Genomic analysis of NmW cultured isolates}

227 To describe the evolutionary relationships of the isolates and particularly those of the cc11, all

228132 cultured isolates (from the period 2010-2016) were subjected to WGS and the data were

229 uploaded to the PubMLST database and analysed using the BIGSdb tools in this database.

230 Isolates grouped into two major clusters corresponding to $\mathrm{cc} 11$ and $\mathrm{cc} 22$. Isolates belonging to

231 other cc were distinct from these two clusters (Fig. 3A). Isolates belonging to "cc22" and to

232 "other cc" showed a higher diversity than "cc11" as suggested by their genetic distances (Fig.3 B

233 and C). Eighty-four isolates belonged to cc11 (of which 70 were identical by MLST) and

234 showed differentiation into two groups that corresponded to the "Anglo-French-Hajj" sub-

235 lineage and to the "South American-UK" sub-lineage (Fig 3A). Few cc11 isolates were

236 separated from the above mentioned two lineages and may correspond to other local cc11

237 isolates that were related to the "Anglo-French-Hajj" sub-lineage (Fig. 3D dashed-line circle). It is noteworthy that isolates 
238 belonging to the "Anglo-French-Hajj" sub-lineage were distributed throughout 2011-2016 (no

239 cc11 was detected in 2010 among all typed cases). In particular, the numbers of isolates related to

240 the "Anglo-French Hajj" strain increased in 2012-2013 and decreased thereafter (only two

241 isolates in 2016) (Fig. 3D). On the other hand, the "South American-UK" isolates were first

242 detected in 2012 and increased thereafter (Fig. 3E). The first case was detected in a patient from

243 United Kingdom who was in holiday in France in June 2012. Isolates belonging to the "South

244 American-UK" sub-lineage represented $45 \%$ of all $\mathrm{NmW}$ cultured isolates from the whole period

245 2010-2016. They increased after 2012 and were the most frequent NmW/cc11 isolates in France

246 in 2016, representing 34 isolates (76\%) of the $45 \mathrm{NmW}$ typed isolates and $94 \%$ of the typed

$247 \mathrm{NmW} / \mathrm{cc} 11$ isolates.

248 Moreover, the "South American-UK" sub-lineage can be further clustered at the genetic level

249 into two distinct strains that corresponded to two temporal periods: "the original UK strain" with

250 isolates from the period 2012-2016 and the "UK 2013-strain" (24) that only included isolates

251 from the period 2015-2016 and increased significantly in 2016. Non-cc11 isolates (cc22 and

252 other cc) did not showed significant variations during the period 2010-2016 (Fig. 4).

253

\section{Epidemiological characteristics of NmW cases according to WGS data}

255 Of 132 isolates typed by WGS, 127 could be matched to clinical and epidemiological data 256 collected through mandatory notification. We compared the characteristics of cases according to

257 four groups defined using WGS data: the "original UK strain", the "UK 2013-strain", the

258 "Anglo-French Hajj" sub-lineage and non-cc11 lineages (Table 2). There was no overall

259 statistical difference in the distribution of cases by age group between these four groups.

260 However a sharp increase in the number of cases due to the "UK 2013-strain" was observed in 2612015 and 2016 in individuals aged 15 years old and over (Fig. 5). In total, there were 36 IMD 
262 cases due to the "UK 2013-strain" among which 34 (94\%) occurred in adults aged 15 years old

263 and over. In the other WGS group, the number of cases in each age group was stable overall the

264 study period, excepting the "Anglo-French Hajj” strain mainly affecting children in 2012.

265 The CFR was $25.9 \%$ among cases within the "South American-UK" sub-lineage and $11.6 \%$ in 266 the other groups (4\% for the "Anglo-French Hajj" and $15.9 \%$ for non cc11) ( $\mathrm{p}=0.04)$. This

267 difference was still observed but not significant when analysing the four lineages / sub-lineages

268 distinctly. Moreover, the CFR was not significantly different between the "original UK strain"

269 and the "UK 2013-strain" ( $\mathrm{p}=0.67)$. Over the period 2010-2016, 15 deaths occurred among cases

270 due the "South American - UK" sub-lineage: 1 death among children aged 0-14 years old (CFR

271 12\%), 3 deaths among the 15-24 years old (CFR 20\%), 9 deaths among the 25-59 years old (CFR

$27243 \%$ ) and 2 deaths among individuals 60 years and over (CFR 14\%).

273 There was no significant association between the infecting strain and the clinical presentation

274 (Table 2).

275 The geographical distribution of IMD cases according to the four WGS groups is shown in Fig. 6 276 suggesting a country-wide expansion of the strains of "South American - UK" sub-lineage in

2772015 and 2016. It is noteworthy that 5 cases due to these strains occurred in persons who reported 278 a city of residence outside France: 2 cases in 2012 who lived in UK and Australia (both "original

279 UK strain"), 2 cases in 2014 who lived in UK ( 1 case due to the "original UK strain" and 1 case 280 due to the "UK 2013-strain") and 1 case in 2015 who lived in UK ("UK 2013-strain). However, 281 without comprehensive information about their history of travel prior to IMD, it is not possible to 282 determine if they acquired the infection in France or in their country of residence. 


\section{Discussion}

Three periods with high number of NmW IMD cases were observed in France in the last

17 years, considering both number of cases and their proportion relatively to all IMD cases: 2000-2003, 2012 and 2016. All of them were caused by NmW/cc11 isolates. Typing analysis showed that most isolates in 2012 clustered within the "Anglo-French Hajj" sub-lineage. This is consistent with a previous report on cases imported from Sub-Saharan countries to France in

2922012 (25). WGS provided additional discrimination compared to the classical MLST approach

293 and showed the emergence of the Anglo-French Hajj strain in 2012 (10). Few other isolates

294 represented local cc11 isolates that were still clustered within the "Anglo-French Hajj" sub-

295 lineage. These isolates may have diverged from a common ancestor introduced in France since at 296 least the year 2000 or may have been imported later on. The last increase in the number of $\mathrm{NmW}$ 297 IMD cases was observed in 2016 and was mostly due to the "UK 2013-strain", which emerged in 298 the UK from the "original UK strain”, a descendant from the South American strains $(13,14,17)$.

299 The strain may now to have expanded even more widely and other countries have reported 300 increase incidence of NmW (Australia, The Netherlands and Spain,) (26-28). The "South 301 American-UK" sub-lineage is distinct from the "Anglo-French Hajj" sub-lineage although all 302 isolates shared the same genotypic formula (W:P1.5,2:F1-1:cc11) suggesting an important role 303 for variation of other bacterial components (17).

304 Surveillance of IMD in France is associated with high exhaustiveness and completeness of data. 305 In a study conducted in 2011, the exhaustiveness was estimated at $91 \%$ for mandatory 306 notification and $84 \%$ for NRCM (data not published). Completeness of data is also very high and 307 has improved in recent years. Since 2010, there has been less than $7 \%$ missing information for 308 the strain group identification and less than 3\% missing information on patients' vital status 309 resulting from IMD. 
310 The CFR was higher for the "South American-UK" sub-lineage compared to the other lineages

311 and sub-lineages which highlights the virulence of this strain as also observed in Chile and the

312 UK $(14,29)$. This strain appears highly transmissible and virulent. Since its emergence in France,

313 the "South American-UK" sub-lineage caused two clusters of cases among university students in

314 France. In both clusters, the "UK 2013-strain" was identified. The first cluster occurred in 2016

315 with three cases among university students in Dijon (Burgundy region). Two deaths were

316 reported. A mass vaccination campaign was organised targeting all students and staff in the

317 campus and no further cases have been reported. Another cluster of 2 cases ( 1 death) occurred in

3182017 among students in a small university in Paris and lead again to the organization of a

319 vaccination campaign (30).

320 A shift in the age of NmW IMD cases has been observed since the introduction of the strains

321 derived from "South American / UK" sub-lineage" in the population in France. In 2015 and 2016,

322 the "UK 2013-strain" affected mainly individuals aged 15 years and over and was rare in children.

323 This shift towards older age groups was not observed for other NmW lineages/sub-lineages

324 during the period 2010-2016, nor in other studies on NmW previously conducted in France (31)

325 (10). Meningococcal isolates carriage and circulation occurs most frequently among adolescents

326 and young adults (32). The shift of IMD to older age groups was suggested as a predictor for

327 epidemic periods of IMD (33). This may reflect the expansion of a new clone in a naïve

328 population and/or higher transmission and virulence properties of the new clone. Similar

329 observations were made in the UK where the increase of NmW/cc11 cases was first reported in

330 older adults during the epidemic year 2012-2013 and then extended downwards, especially to

331 adolescents and infants, by the epidemic year 2014/2015 (14, 34). However, in Chile where the

332 "South American-UK" sub-lineage emerged, in 2011-2012, 47\% of cases were reported in

333 children <5 years (29). Accordingly, vaccination against $\mathrm{NmW}$ was initiated in October 2012 in 
334 children aged 9 months to 5 years using the tetravalent conjugate vaccine. A direct effect was

335 observed in this age group. However, this strategy did not show any impact in other age groups

336 and it was argued that targeting adolescents and young adults may be needed to improve the

337 vaccination strategy against $\mathrm{NmW}$ in Chile (12). In the UK, an adolescent program using 338 MenACWY conjugate vaccine was recommended in 2015 targeting 13-14 years old subjects and

339 university entrants in addition to a catch up campaign for 14-18 year olds during 2015 to 2017

340 (35). A major decrease in the number of $\mathrm{NmW}$ cases was observed in the first vaccine-targeted

341 cohort who entered university (34). The epidemiology of NmW IMD should be followed up

342 carefully in order to guide vaccination strategies. If a vaccination was to be recommended in

343 France, epidemiological data will be instrumental in identifying the optimal target population.

344 Epidemiological data available for the first semester of 2017 are consistent with those presented

345 here and show the persisting increase in the number of NmW IMD cases (32 cases in the first half

346 of 2017 versus 24 cases in the first half of 2016), a high proportion of cases aged 15 years and

347 over (75\%) and a high CFR (31\%). Finally, WGS provided new inputs in the analysis to describe

348 the epidemiological and clinical profile of this emerging strain. We found some specific

349 characteristics linked to the "UK 2013-strain" although comparison between lineages / sub-

350 lineages was probably hampered by the small number of cases in each group. Our work in

351 addition to other studies $(17,24,36)$ provides evidence on the usefulness of combining WGS and

352 epidemiological data to better describe the population expansion and spread of $N$. meningitidis

353 and provides good basis for further work on the routine use of WGS in the surveillance of IMD in

354 France. 


\section{Acknowledgements}

This publication made use of the Neisseria Multi Locus Sequence Typing website (https://pubmlst.org/neisseria/) developed by Keith Jolley and sited at the University of Oxford (22). The development of this site has been funded by the Wellcome Trust and European Union. We also acknowledge the PIBNET-P2M platform at the Institut Pasteur. We would like to thank all biologists and clinicians who notified cases, as well as the regional health agencies and Santé Publique France regional units (Cire) for their contribution to IMD surveillance, and also the persons involved in data management at Santé Publique France (Catherine Maine and Yann Savitch for data entry and Mireille Allemand for mapping). 


\section{References}

1. Rosenstein NE, Perkins BA, Stephens DS, Popovic T, Hughes JM. Meningococcal disease. N Engl J Med. 2001 May 3;344(18):1378-88. PubMed PMID: 11333996.

2. Caugant DA, Maiden MC. Meningococcal carriage and disease--population biology and evolution. Vaccine. 2009 Jun 24;27 Suppl 2:B64-70. PubMed PMID: 19464092. Pubmed Central PMCID: 2719693. Epub 2009/05/26. eng.

3. Harrison OB, Claus H, Jiang Y, Bennett JS, Bratcher HB, Jolley KA, et al. Description and nomenclature of Neisseria meningitidis capsule locus. Emerg Infect Dis. 2013 Apr;19(4):566-73. PubMed PMID: 23628376. Pubmed Central PMCID: 3647402. Epub 2013/05/01. eng.

4. Harrison LH, Pelton SI, Wilder-Smith A, Holst J, Safadi MA, Vazquez JA, et al. The Global Meningococcal Initiative: recommendations for reducing the global burden of meningococcal disease. Vaccine. 2011 Apr 18;29(18):3363-71. PubMed PMID: 21376800. Epub 2011/03/08. eng.

5. Bethell D, Pollard AJ. Meningococcal vaccines. Expert Rev Vaccines. 2002 Jun;1(1):7584. PubMed PMID: 12908514.

6. HCSP. Avis relatif à la vaccination par le vaccin méningococcique conjugué de sérogroupe C www.hcsp.fr/explore.cgi/hcspa20090424_meningC.pdf. 2009.

7. Harrison LH, Trotter CL, Ramsay ME. Global epidemiology of meningococcal disease. Vaccine. 2009 Jun 24;27 Suppl 2:B51-63. PubMed PMID: 19477562.

8. Taha MK, Achtman M, Alonso JM, Greenwood B, Ramsay M, Fox A, et al. Serogroup W135 meningococcal disease in Hajj pilgrims. Lancet. 2000 Dec 23-30;356(9248):2159. PubMed PMID: 11191548.

9. Collard JM, Maman Z, Yacouba H, Djibo S, Nicolas P, Jusot JF, et al. Increase in Neisseria meningitidis serogroup W135, Niger, 2010. Emerg Infect Dis. 2010 Sep;16(9):1496-8. PubMed PMID: 20735947. Epub 2010/08/26. eng.

10. Taha MK, Kacou-N'douba A, Hong E, Deghmane AE, Giorgini D, Okpo SL, et al. Travel-related Neisseria meningitidis Serogroup W135 Infection, France. Emerg Infect Dis. 2013 Jun;19(6):1030-2. PubMed PMID: 23735310. Epub 2013/06/06. eng.

11. Traore Y, Njanpop-Lafourcade BM, Adjogble KL, Lourd M, Yaro S, Nacro B, et al. The rise and fall of epidemic Neisseria meningitidis serogroup W135 meningitis in Burkina Faso, 2002-2005. Clin Infect Dis. 2006 Oct 1;43(7):817-22. PubMed PMID: 16941360.

12. Safadi MA, O'Ryan M, Valenzuela Bravo MT, Brandileone MC, Gorla MC, de Lemos AP, et al. The current situation of meningococcal disease in Latin America and updated Global Meningococcal Initiative (GMI) recommendations. Vaccine. 2015 Nov 27;33(48):6529-36. PubMed PMID: 26597036. Epub 2015/11/26. eng.

13. Abad R, Lopez EL, Debbag R, Vazquez JA. Serogroup W meningococcal disease: global spread and current affect on the Southern Cone in Latin America. Epidemiol Infect. 2014 May 15:1-10. PubMed PMID: 24831052. Epub 2014/05/17. Eng.

14. Ladhani SN, Beebeejaun K, Lucidarme J, Campbell H, Gray S, Kaczmarski E, et al. Increase in Endemic Neisseria meningitidis Capsular Group W Sequence Type 11 Complex Associated With Severe Invasive Disease in England and Wales. Clin Infect Dis. 2015 Feb 15;60(4):578-85. PubMed PMID: 25389259. Epub 2014/11/13. eng.

15. Maiden MC, Bygraves JA, Feil E, Morelli G, Russell JE, Urwin R, et al. Multilocus sequence typing: a portable approach to the identification of clones within populations of 
pathogenic microorganisms. Proc Natl Acad Sci U S A. 1998 Mar 17;95(6):3140-5. PubMed PMID: 9501229.

16. Maiden MC, van Rensburg MJ, Bray JE, Earle SG, Ford SA, Jolley KA, et al. MLST revisited: the gene-by-gene approach to bacterial genomics. Nat Rev Microbiol. 2013 Oct;11(10):728-36. PubMed PMID: 23979428. Epub 2013/08/28. eng.

17. Lucidarme J, Hill DM, Bratcher HB, Gray SJ, du Plessis M, Tsang RS, et al. Genomic resolution of an aggressive, widespread, diverse and expanding meningococcal serogroup $\mathrm{B}, \mathrm{C}$ and W lineage. J Infect. 2015 Nov;71(5):544-52. PubMed PMID: 26226598. Pubmed Central PMCID: 4635312. Epub 2015/08/01. eng.

18. Taha MK, Giorgini D, Ducos-Galand M, Alonso JM. Continuing diversification of Neisseria meningitidis W135 as a primary cause of meningococcal disease after emergence of the serogroup in 2000. J Clin Microbiol. 2004 Oct;42(9):4158-63. PubMed PMID: 15365005.

19. Parent du Chatelet I, Deghmane AE, Antona D, Hong E, Fonteneau L, Taha MK, et al. Characteristics and changes in invasive meningococcal disease epidemiology in France, 20062015. J Infect. 2017 Mar 07;74:564-74. PubMed PMID: 28279715. Epub 2017/03/11. eng.

20. Taha MK, Alonso JM, Cafferkey M, Caugant DA, Clarke SC, Diggle MA, et al. Interlaboratory comparison of PCR-based identification and genogrouping of Neisseria meningitidis. J Clin Microbiol. 2005 Jan;43(1):144-9. PubMed PMID: 15634963.

21. Veyrier FJ, Hong E, Deghmane AE, Taha MK. Draft Genome Sequence of a Neisseria meningitidis Serogroup C Isolate of Sequence Type 11 Linked to an Outbreak among Men Who Have Sex with Men. Genome Announc. 2013;1(5). PubMed PMID: 24092789. Epub 2013/10/05. Eng.

22. Jolley KA, Maiden MC. BIGSdb: Scalable analysis of bacterial genome variation at the population level. BMC Bioinformatics. 2010;11:595. PubMed PMID: 21143983. Pubmed Central PMCID: 3004885. Epub 2010/12/15. eng.

23. Huson DH, Bryant D. Application of phylogenetic networks in evolutionary studies. Mol Biol Evol. 2006 Feb;23(2):254-67. PubMed PMID: 16221896.

24. Lucidarme J, Scott KJ, Ure R, Smith A, Lindsay D, Stenmark B, et al. An international invasive meningococcal disease outbreak due to a novel and rapidly expanding serogroup $\mathrm{W}$ strain, Scotland and Sweden, July to August 2015. Euro Surveill. 2016 Nov 10;21(45). PubMed PMID: 27918265. Pubmed Central PMCID: 5144941. Epub 2016/12/06. eng.

25. Parent du Chatelet I, Barboza P, Taha MK. W135 invasive meningococcal infections imported from Sub-Saharan Africa to France, January to April 2012. Euro Surveill. 2012 May 24;17(21). PubMed PMID: 22687826. Epub 2012/06/13. eng.

26. Russcher A, Fanoy E, van Olden GDJ, Graafland AD, van der Ende A, Knol MJ. Necrotising fasciitis as atypical presentation of infection with emerging Neisseria meningitidis serogroup W (MenW) clonal complex 11, the Netherlands, March 2017. Euro Surveill. 2017 Jun 08;22(23). PubMed PMID: 28661395. Epub 2017/07/01. eng.

27. Carville KS, Stevens K, Sohail A, Franklin LJ, Bond KA, Brahmi A, et al. Increase in Meningococcal Serogroup W Disease, Victoria, Australia, 2013-2015. Emerg Infect Dis. 2016 Oct;22(10):1785-7. PubMed PMID: 27648521. Epub 2016/09/21. eng.

28. Abad R, Vazquez JA. Early evidence of expanding W ST-11 CC meningococcal incidence in Spain. J Infect. 2016 Sep;73(3):296-7. PubMed PMID: 27387450. Epub 2016/07/09. eng.

29. Valenzuela MT, Moreno G, Vaquero A, Seoane M, Hormazabal JC, Bertoglia MP, et al. [Emergence of W135 meningococcal serogroup in Chile during 2012]. Rev Med Chil. 2013 
Aug;141(8):959-67. PubMed PMID: 24448851. Epub 2014/01/23. Emergencia de la cepa W135 causante de enfermedad meningococica invasora en Chile 2012. spa.

30. Bassi C, Taha MK, Merle C, Hong E, Levy-Bruhl D, Barret AS, et al. A cluster of invasive meningococcal disease (IMD) caused by Neisseria meningitidis serogroup $\mathrm{W}$ among university students, France, February to May 2017. Euro Surveill. 2017 Jul 13;22(28). PubMed PMID: 28749333. Epub 2017/07/28. eng.

31. Gaschignard J, Levy C, Deghmane AE, Dubos F, Muszlak M, Cohen R, et al. Invasive serogroup w meningococcal disease in children: a national survey from 2001 to 2008 in france. Pediatr Infect Dis J. 2013 Jul;32(7):798-800. PubMed PMID: 23838782. Epub 2013/07/11. eng. 32. Christensen H, May M, Bowen L, Hickman M, Trotter CL. Meningococcal carriage by age: a systematic review and meta-analysis. Lancet Infect Dis. 2010 Dec;10(12):853-61. PubMed PMID: 21075057.

33. Peltola H, Kataja JM, Makela PH. Shift in the age-distribution of meningococcal disease as predictor of an epidemic? Lancet. 1982 Sep 11;2(8298):595-7. PubMed PMID: 6125738.

34. Campbell H, Edelstein M, Andrews N, Borrow R, Ramsay M, Ladhani S. Emergency Meningococcal ACWY Vaccination Program for Teenagers to Control Group W Meningococcal Disease, England, 2015-2016. Emerg Infect Dis. 2017 Jul 15;23(7). PubMed PMID: 28409739. Epub 2017/04/15. eng.

35. Ladhani SN, Ramsay M, Borrow R, Riordan A, Watson JM, Pollard AJ. Enter B and W: two new meningococcal vaccine programmes launched. Arch Dis Child. 2016 Jan;101(1):91-5. PubMed PMID: 26672098. Pubmed Central PMCID: 4717420. Epub 2015/12/17. eng.

36. Hill DM, Lucidarme J, Gray SJ, Newbold LS, Ure R, Brehony C, et al. Genomic epidemiology of age-associated meningococcal lineages in national surveillance: an observational cohort study. Lancet Infect Dis. 2015 Dec;15(12):1420-8. PubMed PMID: 26515523. Pubmed Central PMCID: 4655307. Epub 2015/10/31. eng. 
Table 1: Characteristics of invasive meningococcal disease (IMD) cases according to strain groups, France, 2015-2016 (source: mandatory notification and National reference centre for meningococci)

NB: data are presented for the most frequent groups

\begin{tabular}{|c|c|c|c|c|c|c|c|c|}
\hline & \multicolumn{5}{|c|}{ For each group } & \multicolumn{3}{|c|}{$\begin{array}{l}\text { For group W versus other groups } \\
\qquad \text { (BCY) }\end{array}$} \\
\hline & $\begin{array}{c}\text { Group B } \\
(n=503) \\
n(\%)\end{array}$ & $\begin{array}{c}\text { Group C } \\
(n=253) \\
n(\%)\end{array}$ & $\begin{array}{c}\text { Group W } \\
(n=77) \\
n(\%)\end{array}$ & $\begin{array}{c}\text { Group Y } \\
\text { (n=116) } \\
n(\%)\end{array}$ & $\begin{array}{c}\text { p- } \\
\text { value }\end{array}$ & $\begin{array}{c}\text { Group } \\
\text { W } \\
(n=77) \\
n(\%)\end{array}$ & $\begin{array}{c}\text { Group } \\
\text { BCY } \\
(n=872) \\
n(\%)\end{array}$ & $\begin{array}{c}\text { p-value (W vs } \\
\text { BWY) }\end{array}$ \\
\hline Age group (years) & & & & & $<10^{-3}$ & & & 0.003 \\
\hline $0-14$ & $\begin{array}{c}243 \\
(48.3)\end{array}$ & $89(35.2)$ & $15(19.5)$ & $\begin{array}{c}23 \\
(19.8)\end{array}$ & & $\begin{array}{c}15 \\
(19.5)\end{array}$ & $\begin{array}{c}355 \\
(40.7)\end{array}$ & \\
\hline $15-24$ & $\begin{array}{c}100 \\
(19.9)\end{array}$ & $54(21.3)$ & $21(27.3)$ & $\begin{array}{c}20 \\
(17.2)\end{array}$ & & $\begin{array}{c}21 \\
(27.3)\end{array}$ & $\begin{array}{c}174 \\
(20.0)\end{array}$ & \\
\hline $25-59$ & $\begin{array}{c}104 \\
(20.7)\end{array}$ & $60(23.7)$ & $21(27.3)$ & $\begin{array}{c}24 \\
(20.7)\end{array}$ & & $\begin{array}{c}21 \\
(27.3)\end{array}$ & $\begin{array}{c}188 \\
(21.6)\end{array}$ & \\
\hline$\geq 60$ & $\begin{array}{c}56 \\
(11.1)\end{array}$ & $50(19.8)$ & $20(26.0)$ & $\begin{array}{c}49 \\
(42.2)\end{array}$ & & $\begin{array}{c}20 \\
(26.0)\end{array}$ & $\begin{array}{c}155 \\
(17.8)\end{array}$ & \\
\hline No. of deaths & $\begin{array}{c}39 \\
(7.8)\end{array}$ & $\begin{array}{c}31 \\
(12.3)\end{array}$ & $17(22.1)$ & $\begin{array}{c}30 \\
(17.2)\end{array}$ & $<10^{-3}$ & $\begin{array}{c}90 \\
(10.4)\end{array}$ & $\begin{array}{c}17 \\
(22.1)\end{array}$ & 0.002 \\
\hline \multicolumn{9}{|l|}{$\begin{array}{l}\text { Clinical } \\
\text { presentation } \\
\text { (several sites of } \\
\text { infection are } \\
\text { possible) }\end{array}$} \\
\hline Meningitis & $\begin{array}{c}408 \\
(81.1)\end{array}$ & $\begin{array}{c}166 \\
(65.6)\end{array}$ & $44(57.1)$ & $\begin{array}{c}71 \\
(61.2)\end{array}$ & $<10^{-3}$ & $\begin{array}{c}44 \\
(57.1)\end{array}$ & $\begin{array}{c}645 \\
(74.0)\end{array}$ & 0.002 \\
\hline Septicemia & $\begin{array}{c}254 \\
(50.5)\end{array}$ & $\begin{array}{c}152 \\
(60.1)\end{array}$ & 60 (77.9) & $\begin{array}{c}90 \\
(77.6)\end{array}$ & $<10^{-3}$ & $\begin{array}{c}60 \\
(77.9)\end{array}$ & $\begin{array}{c}496 \\
(56.9)\end{array}$ & $<10^{-3}$ \\
\hline Arthritis & $\begin{array}{c}7 \\
(1.3)\end{array}$ & $\begin{array}{c}19 \\
(7.5)\end{array}$ & $\begin{array}{c}7 \\
(9.1)\end{array}$ & $\begin{array}{c}5 \\
(4.3)\end{array}$ & $<10^{-3}$ & $\begin{array}{c}7 \\
(9.1)\end{array}$ & $\begin{array}{c}31 \\
(3.6)\end{array}$ & 0.01 \\
\hline Purpura fulminans & $\begin{array}{c}113 \\
(24.8)\end{array}$ & $56(24.1)$ & $\begin{array}{c}8 \\
(13.1)\end{array}$ & $\begin{array}{c}9 \\
(9.1)\end{array}$ & 0.002 & $\begin{array}{c}8 \\
(13.1)\end{array}$ & $\begin{array}{c}178 \\
(22.7)\end{array}$ & 0.08 \\
\hline
\end{tabular}


Table 2: Characteristics of $\mathrm{NmW}$ invasive meningococcal disease (IMD) cases according to thefour lineages/sub-lineages identified by Whole-Genome Sequencing (WGS), France, 20102016 (source: mandatory notification and National reference centre for meningococci)

\begin{tabular}{ccccc} 
Original UK strain & UK 2013-strain & $\begin{array}{c}\text { Anglo- } \\
\text { French } \\
\text { Hajj }\end{array}$ & $\begin{array}{c}\text { Not cc11 } \\
\text { lineages }\end{array}$ & p-value \\
$\mathrm{N}=22$ & $\mathrm{~N}=36$ & $\mathrm{~N}=25$ & $\mathrm{~N}=44$ & \\
$\mathrm{n}(\%)$ & $\mathrm{n}(\%)$ & $\mathrm{n}(\%)$ & & \\
\hline
\end{tabular}

\begin{tabular}{|c|c|c|c|c|c|}
\hline Age (years) & & & & & 0.09 \\
\hline $0-14$ & $6(27.3)$ & $2(5.6)$ & $9(36.0)$ & $10(22.7)$ & \\
\hline $15-24$ & $3(13.7)$ & $12(33.3)$ & $4(16.0)$ & $9(20.4)$ & \\
\hline $25-59$ & $8(36.4)$ & $13(36.1)$ & $7(28.0)$ & $9(20.4)$ & \\
\hline$\geq 60$ & $5(22.7)$ & $9(25.0)$ & $5(20.0)$ & $16(36.4)$ & \\
\hline Case fatality rate & $5(22.7)$ & $10(27.8)$ & $1(4.0)$ & 7 (15.9) & 0.08 \\
\hline \multicolumn{6}{|l|}{$\begin{array}{l}\text { Clinical } \\
\text { presentation } \\
\text { (several sites of } \\
\text { infection are } \\
\text { possible) }\end{array}$} \\
\hline Meningitis & $12(54.5)$ & $20(55.6)$ & $16(64.0)$ & $20(45.4)$ & 0.51 \\
\hline Septicemia & $17(77.3)$ & $30(83.3)$ & $18(72.0)$ & $31(70.4)$ & 0.57 \\
\hline Arthritis & $1(4.5)$ & $4(11.1)$ & $3(12.0)$ & $4(9.1)$ & 0.87 \\
\hline Purpura fulminans & $3(17.6)$ & $4(13.3)$ & $2(8.3)$ & 5 (13.9) & 0.85 \\
\hline
\end{tabular}


Figure 1: Number of NmW invasive meningococcal disease (IMD) cases and proportion of $\mathrm{NmW}$ over all IMD cases, France, 2000-2016 (source: mandatory notification and National reference centre for meningococci)

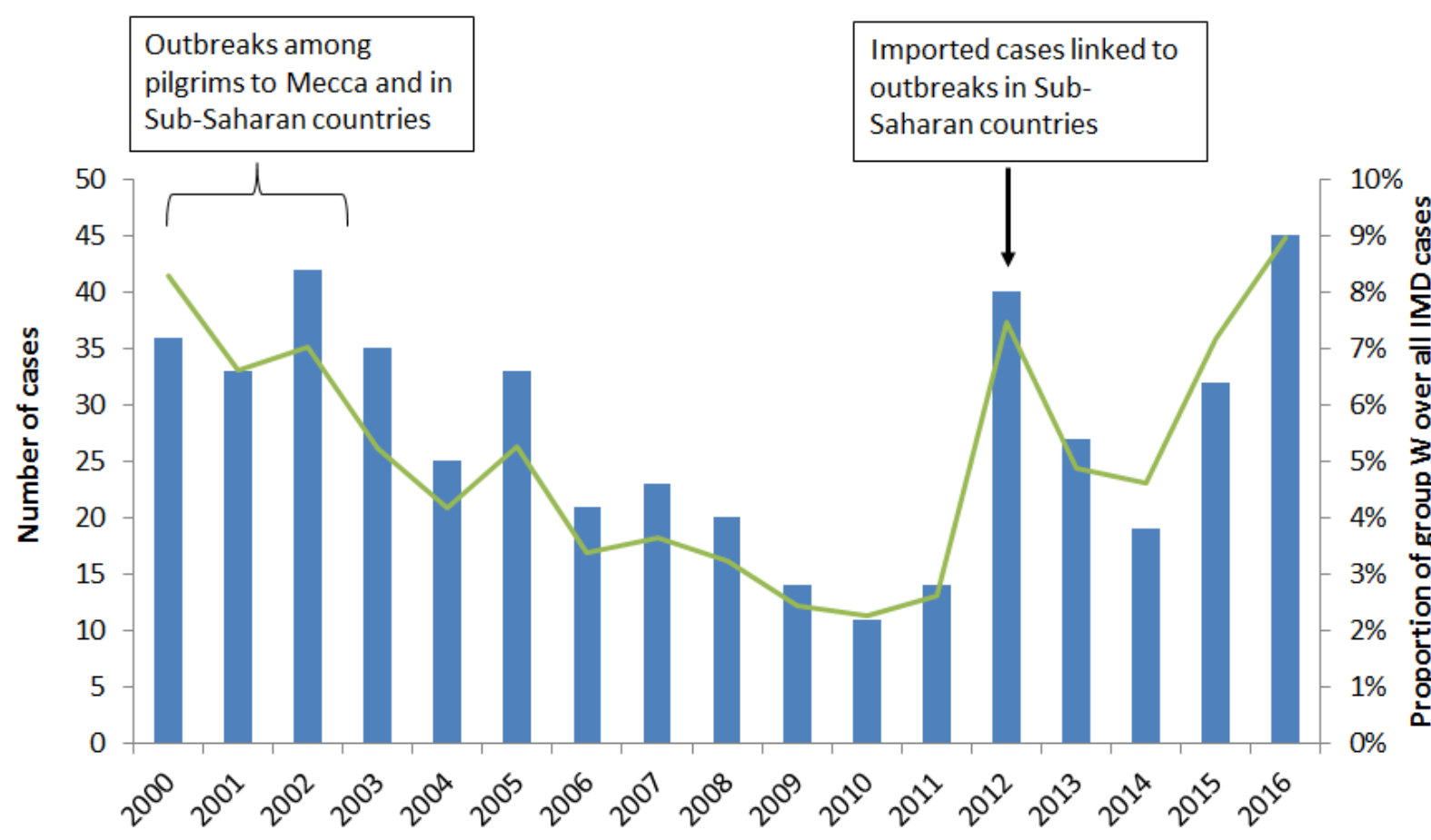


Figure 2: Annual distribution of NmW invasive meningococcal disease (IMD) corresponding to both culture- and non-culture-confirmed cases by major clonal complexes characterised by the National reference centre for meningococci (NRCM), France, 2000-2016. For the period 20002009, MLST typing was not systematically performed and MLST data were obtained for 52\% to $100 \%$ of cases. Missing data in the period 2010-2016 correspond to non-culture cases. PCR was added in the mandatory reporting criteria in 2002, explaining the discrepancy in number of cases between figure 1 and 2 for the period 2000-2002

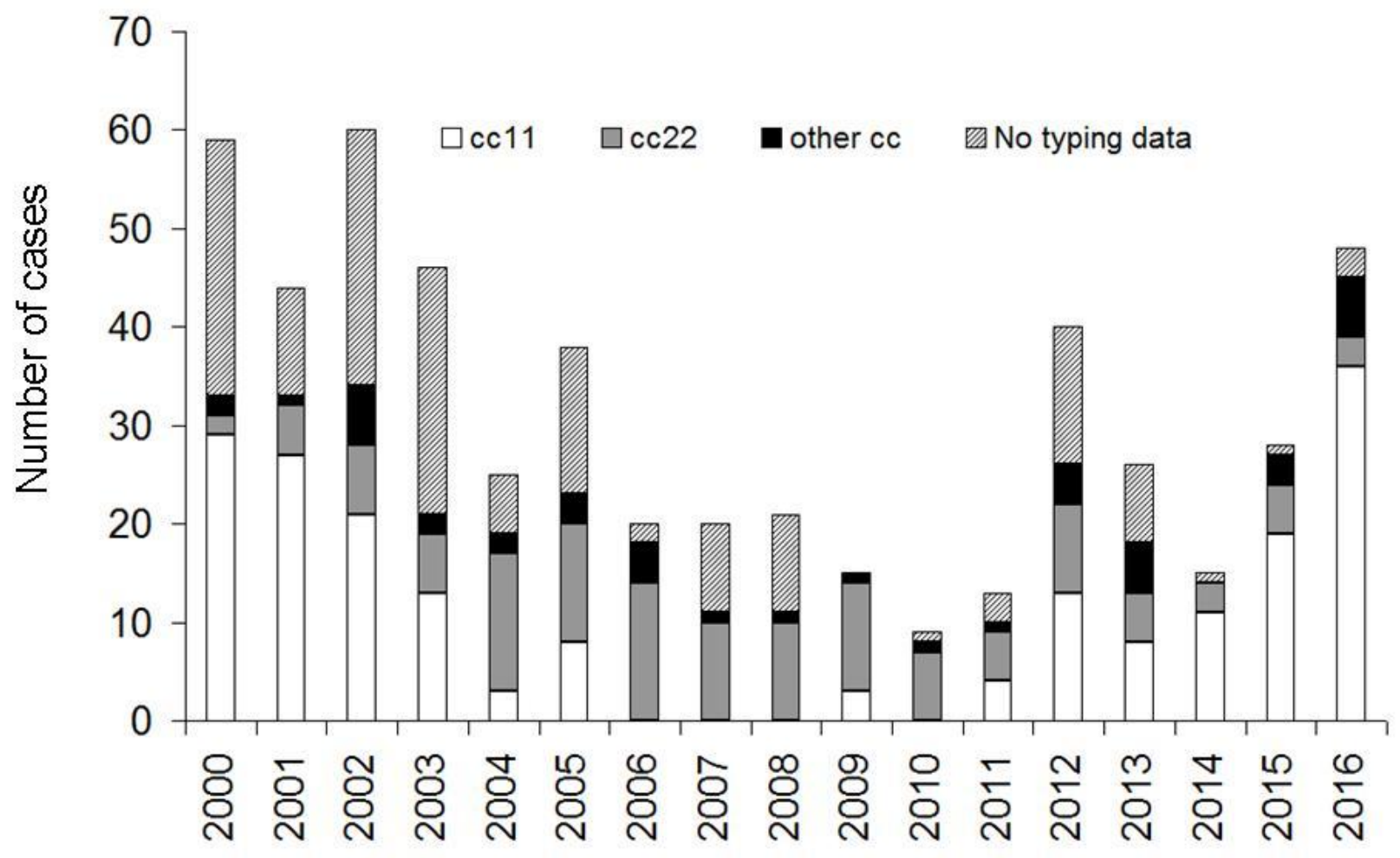


Figure 3 : Neighbour-net phylogenetic network of all invasive NmW cultured isolates received at the national reference centre for meningococci, France, 2010-2016 (A) Global view of the phylogenetic tree showing all the genetic lineages identified. In (B) and (C) a zoom on the tree that includes the non cc11 isolates (cc22 and other cc isolates). In (D) are depicted a zoom on the cc11 isolates that were resolved into the Anglo-French-Hajj sub-lineage. One isolates representative to the Hajj 2000 outbreak was included (ID31165 red arrow). The isolates that were highly related to the Hajj strain were surrounded by a solid line circle and those that were more distantly related to the Hajj strain surrounded by a dashed line circle. (E) The South American-UK sub-lineage that included the two strains: the original UK strain and the UK 2013strain according to (24). One representative isolate (ID20196) for the "original UK strain" was indicated by a red arrow. One representative isolate (ID30167) for the "UK 2013-strain" was indicated by a blue arrow. The coloured circles represent individual isolates for each year of the period 2010-2016.

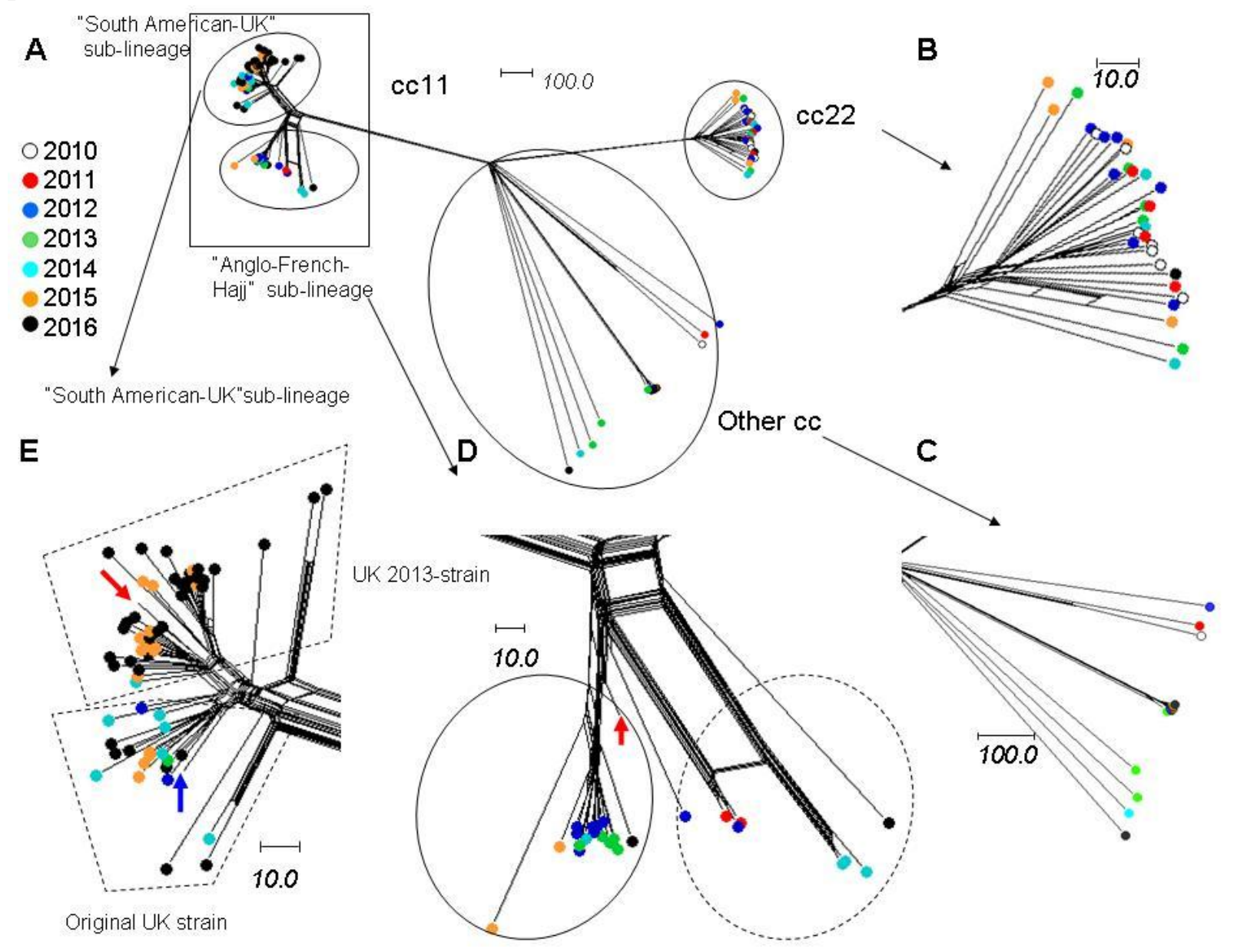


Figure 4: Annual distribution of NmW invasive meningococcal disease (IMD) isolates by WGS sub-lineage characterised by the National reference centre for meningococci, France, 2010-2016. Cases are classified in four groups using WGS data: "original UK strain", "UK 2013-strain", Anglo-French-Hajj and non-cc11.

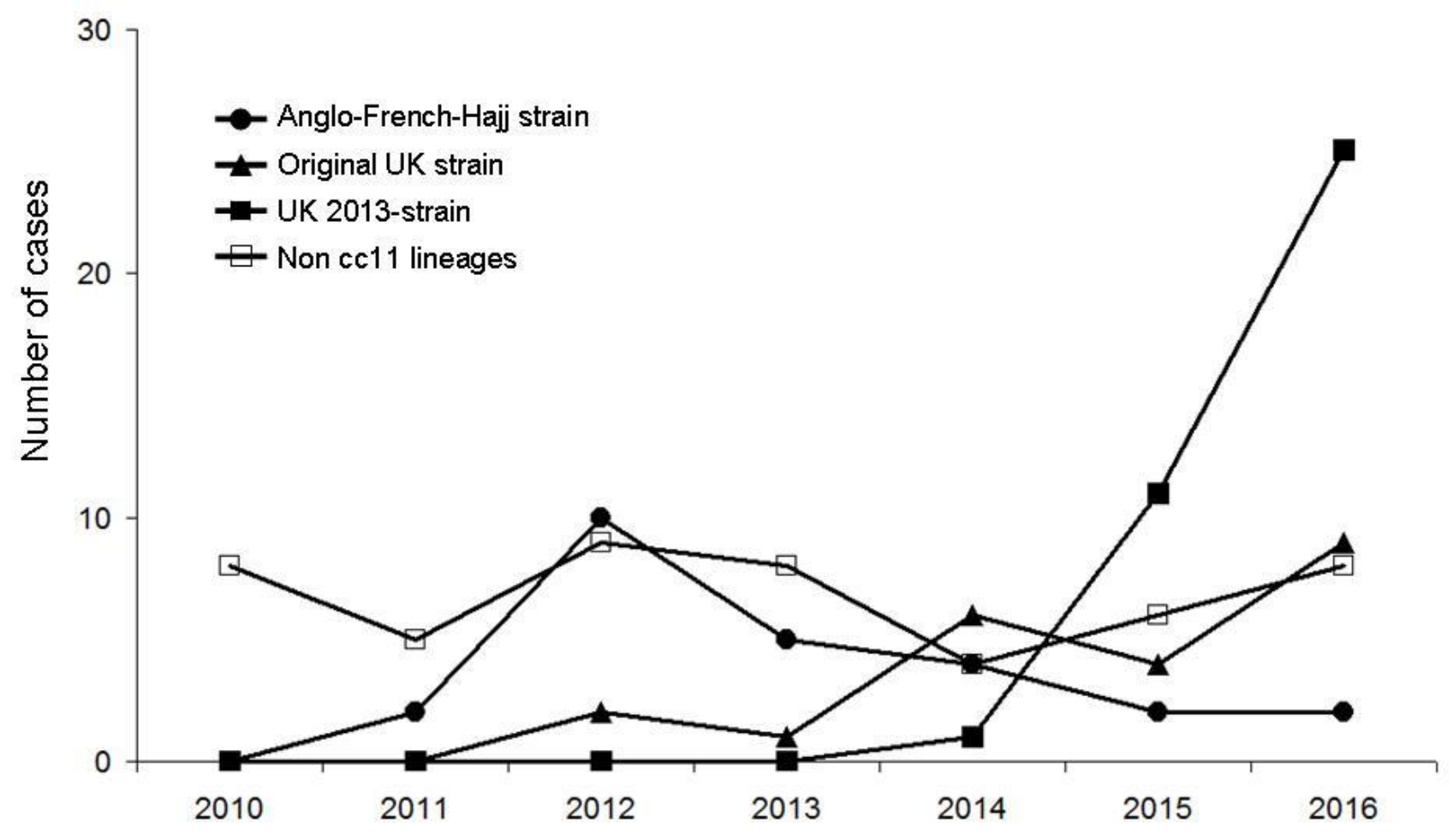


Figure 5: Number of NmW invasive meningococcal disease (IMD) cases by age group and year, according to the four lineages/sub-lineages identified by WGS, France, 2010-2016

Cases are classified in four groups using WGS data: “original UK strain”, “UK 2013-strain”, Anglo-French-Hajj and non-cc11.

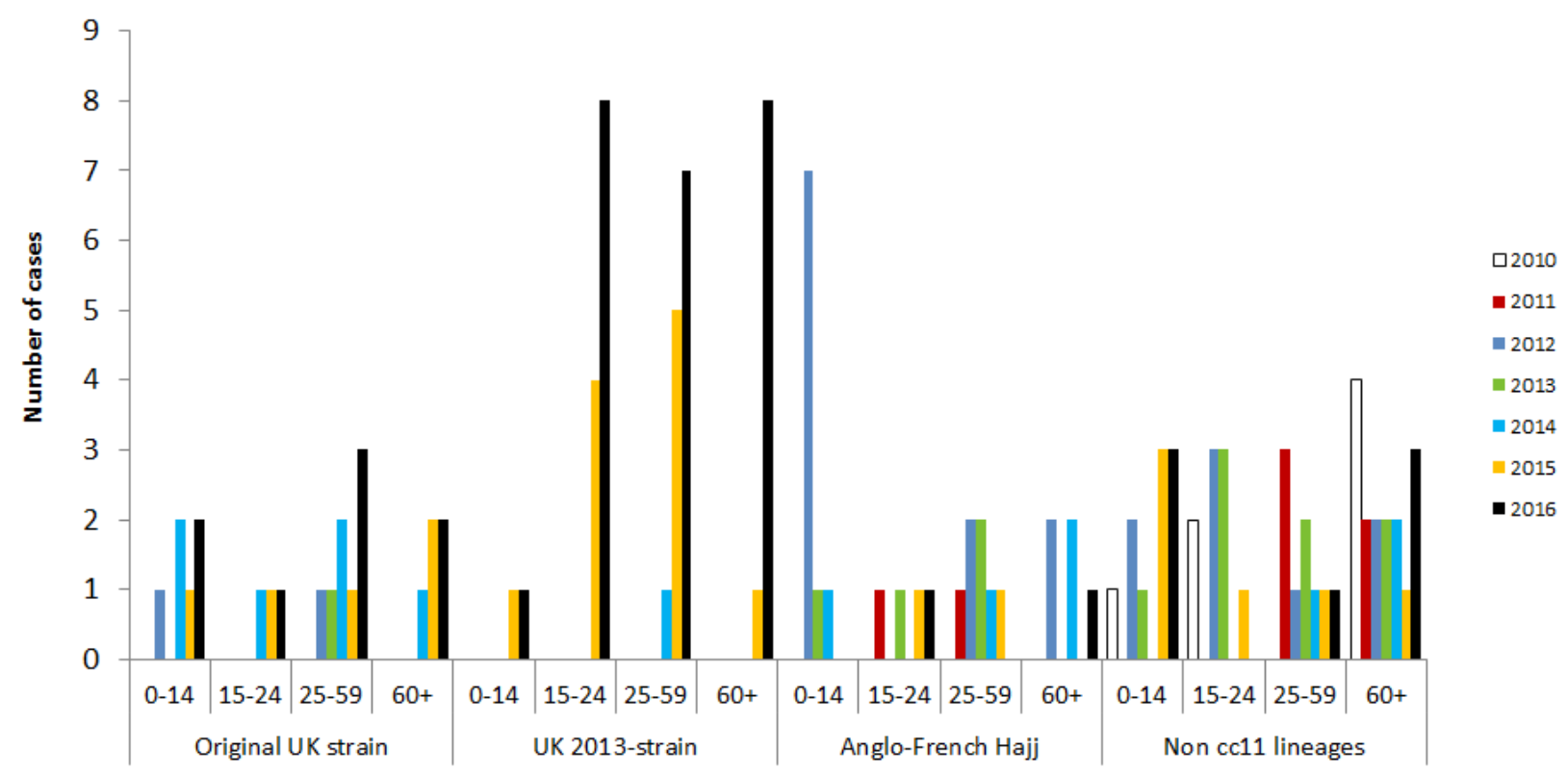


Figure 6

Geographic distribution of $\mathrm{NmW}$ invasive meningococcal disease (IMD) cases according to their place of residence, France, 2010-2016.

Cases are classified in four groups using WGS data: “original UK strain”, "UK 2013-strain”, Anglo-French-Hajj and non-cc11.
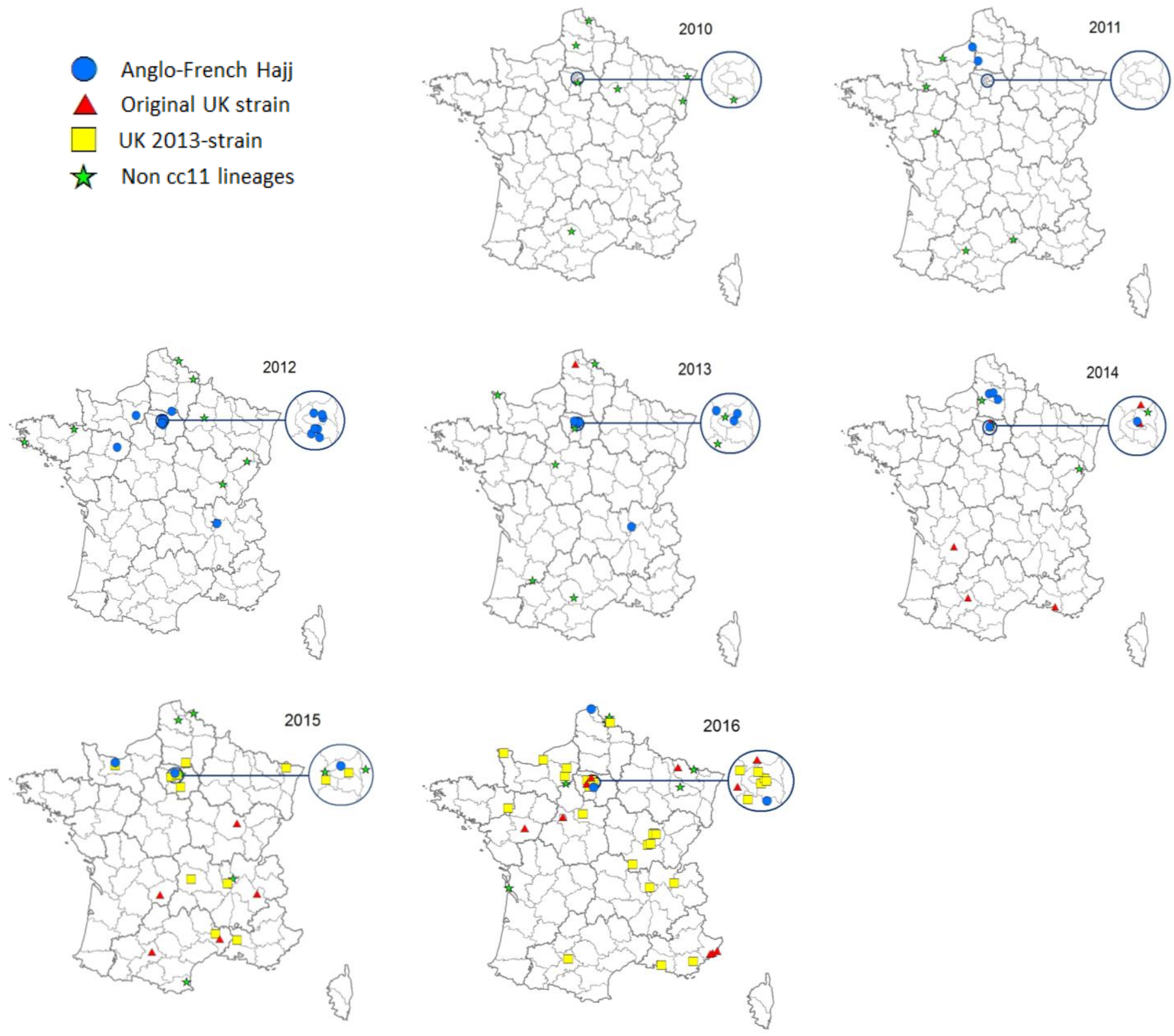
Table 1: Characteristics of invasive meningococcal disease (IMD) cases according to strain groups, France, 2015-2016 (source: mandatory notification and National reference centre for meningococci)

NB: data are presented for the most frequent groups

\begin{tabular}{|c|c|c|c|c|c|c|c|c|}
\hline & \multicolumn{5}{|c|}{ For each group } & \multicolumn{3}{|c|}{$\begin{array}{l}\text { For group } W \text { versus other groups } \\
\qquad(\mathrm{BCY})\end{array}$} \\
\hline & $\begin{array}{c}\text { Group B } \\
(n=503) \\
n(\%)\end{array}$ & $\begin{array}{c}\text { Group C } \\
(n=253) \\
n(\%)\end{array}$ & $\begin{array}{c}\text { Group W } \\
(n=77) \\
n(\%)\end{array}$ & $\begin{array}{c}\text { Group } Y \\
(n=116) \\
n(\%)\end{array}$ & $\begin{array}{c}\mathrm{p}- \\
\text { value }\end{array}$ & $\begin{array}{c}\text { Group } \\
W \\
(n=77) \\
n(\%)\end{array}$ & $\begin{array}{c}\text { Group } \\
\text { BCY } \\
(n=872) \\
n(\%)\end{array}$ & $\begin{array}{c}\text { p-value (W vs } \\
\text { BWY) }\end{array}$ \\
\hline Age group (years) & & & & & $<10^{-3}$ & & & 0.003 \\
\hline $0-14$ & $\begin{array}{c}243 \\
(48.3)\end{array}$ & $89(35.2)$ & $15(19.5)$ & $\begin{array}{c}23 \\
(19.8)\end{array}$ & & $\begin{array}{c}15 \\
(19.5)\end{array}$ & $\begin{array}{c}355 \\
(40.7)\end{array}$ & \\
\hline $15-24$ & $\begin{array}{c}100 \\
(19.9)\end{array}$ & $54(21.3)$ & $21(27.3)$ & $\begin{array}{c}20 \\
(17.2)\end{array}$ & & $\begin{array}{c}21 \\
(27.3)\end{array}$ & $\begin{array}{c}174 \\
(20.0)\end{array}$ & \\
\hline $25-59$ & $\begin{array}{c}104 \\
(20.7)\end{array}$ & $60(23.7)$ & $21(27.3)$ & $\begin{array}{c}24 \\
(20.7)\end{array}$ & & $\begin{array}{c}21 \\
(27.3)\end{array}$ & $\begin{array}{c}188 \\
(21.6)\end{array}$ & \\
\hline$\geq 60$ & $\begin{array}{c}56 \\
(11.1)\end{array}$ & $50(19.8)$ & $20(26.0)$ & $\begin{array}{c}49 \\
(42.2)\end{array}$ & & $\begin{array}{c}20 \\
(26.0)\end{array}$ & $\begin{array}{c}155 \\
(17.8)\end{array}$ & \\
\hline No. of deaths & $\begin{array}{c}39 \\
(7.8)\end{array}$ & $\begin{array}{c}31 \\
(12.3)\end{array}$ & $17(22.1)$ & $\begin{array}{c}30 \\
(17.2)\end{array}$ & $<10^{-3}$ & $\begin{array}{c}90 \\
(10.4)\end{array}$ & $\begin{array}{c}17 \\
(22.1)\end{array}$ & 0.002 \\
\hline \multicolumn{9}{|l|}{$\begin{array}{l}\text { Clinical } \\
\text { presentation } \\
\text { (several sites of } \\
\text { infection are } \\
\text { possible) }\end{array}$} \\
\hline Meningitis & $\begin{array}{c}408 \\
(81.1)\end{array}$ & $\begin{array}{c}166 \\
(65.6)\end{array}$ & $44(57.1)$ & $\begin{array}{c}71 \\
(61.2)\end{array}$ & $<10^{-3}$ & $\begin{array}{c}44 \\
(57.1)\end{array}$ & $\begin{array}{c}645 \\
(74.0)\end{array}$ & 0.002 \\
\hline Septicemia & $\begin{array}{c}254 \\
(50.5)\end{array}$ & $\begin{array}{c}152 \\
(60.1)\end{array}$ & 60 (77.9) & $\begin{array}{c}90 \\
(77.6)\end{array}$ & $<10^{-3}$ & $\begin{array}{c}60 \\
(77.9)\end{array}$ & $\begin{array}{c}496 \\
(56.9)\end{array}$ & $<10^{-3}$ \\
\hline Arthritis & $\begin{array}{c}7 \\
(1.3)\end{array}$ & $\begin{array}{c}19 \\
(7.5)\end{array}$ & $\begin{array}{c}7 \\
(9.1)\end{array}$ & $\begin{array}{c}5 \\
(4.3)\end{array}$ & $<10^{-3}$ & $\begin{array}{c}7 \\
(9.1)\end{array}$ & $\begin{array}{c}31 \\
(3.6)\end{array}$ & 0.01 \\
\hline Purpura fulminans & $\begin{array}{c}113 \\
(24.8)\end{array}$ & $56(24.1)$ & $\begin{array}{c}8 \\
(13.1)\end{array}$ & $\begin{array}{c}9 \\
(9.1)\end{array}$ & 0.002 & $\begin{array}{c}8 \\
(13.1)\end{array}$ & $\begin{array}{c}178 \\
(22.7)\end{array}$ & 0.08 \\
\hline
\end{tabular}


Table 2: Characteristics of $\mathrm{NmW}$ invasive meningococcal disease (IMD) cases according to thefour lineages/sub-lineages identified by Whole-Genome Sequencing (WGS), France, 20102016 (source: mandatory notification and National reference centre for meningococci)

\begin{tabular}{ccccc} 
Original UK strain & UK 2013-strain & $\begin{array}{c}\text { Anglo- } \\
\text { French } \\
\text { Hajj }\end{array}$ & $\begin{array}{c}\text { Not cc11 } \\
\text { lineages }\end{array}$ & p-value \\
$\mathrm{N}=22$ & $\mathrm{~N}=36$ & $\mathrm{~N}=25$ & $\mathrm{~N}=44$ & \\
$\mathrm{n}(\%)$ & $\mathrm{n}(\%)$ & $\mathrm{n}(\%)$ & & \\
\hline
\end{tabular}

\begin{tabular}{|c|c|c|c|c|c|}
\hline Age (years) & & & & & 0.09 \\
\hline $0-14$ & $6(27.3)$ & $2(5.6)$ & $9(36.0)$ & $10(22.7)$ & \\
\hline $15-24$ & $3(13.7)$ & $12(33.3)$ & $4(16.0)$ & $9(20.4)$ & \\
\hline $25-59$ & $8(36.4)$ & $13(36.1)$ & $7(28.0)$ & $9(20.4)$ & \\
\hline$\geq 60$ & $5(22.7)$ & $9(25.0)$ & $5(20.0)$ & $16(36.4)$ & \\
\hline Case fatality rate & $5(22.7)$ & $10(27.8)$ & $1(4.0)$ & $7(15.9)$ & 0.08 \\
\hline \multicolumn{6}{|l|}{$\begin{array}{l}\text { Clinical } \\
\text { presentation } \\
\text { (several sites of } \\
\text { infection are } \\
\text { possible) }\end{array}$} \\
\hline Meningitis & $12(54.5)$ & $20(55.6)$ & $16(64.0)$ & $20(45.4)$ & 0.51 \\
\hline Septicemia & $17(77.3)$ & $30(83.3)$ & $18(72.0)$ & $31(70.4)$ & 0.57 \\
\hline Arthritis & $1(4.5)$ & $4(11.1)$ & $3(12.0)$ & $4(9.1)$ & 0.87 \\
\hline Purpura fulminans & $3(17.6)$ & $4(13.3)$ & $2(8.3)$ & $5(13.9)$ & 0.85 \\
\hline
\end{tabular}




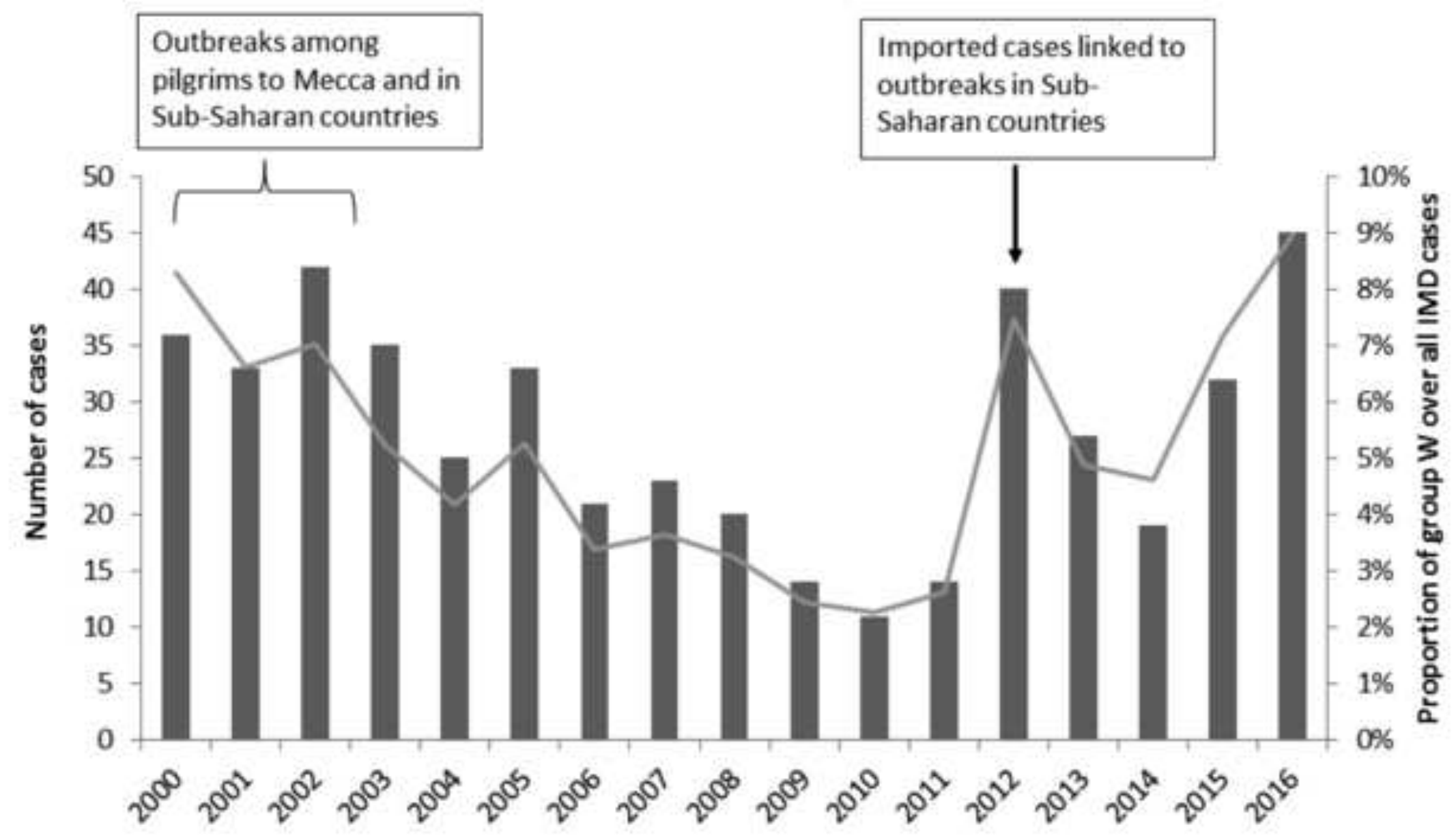

Imported cases linked to

outbreaks in Sub-

Saharan countries

$10 \%$

 


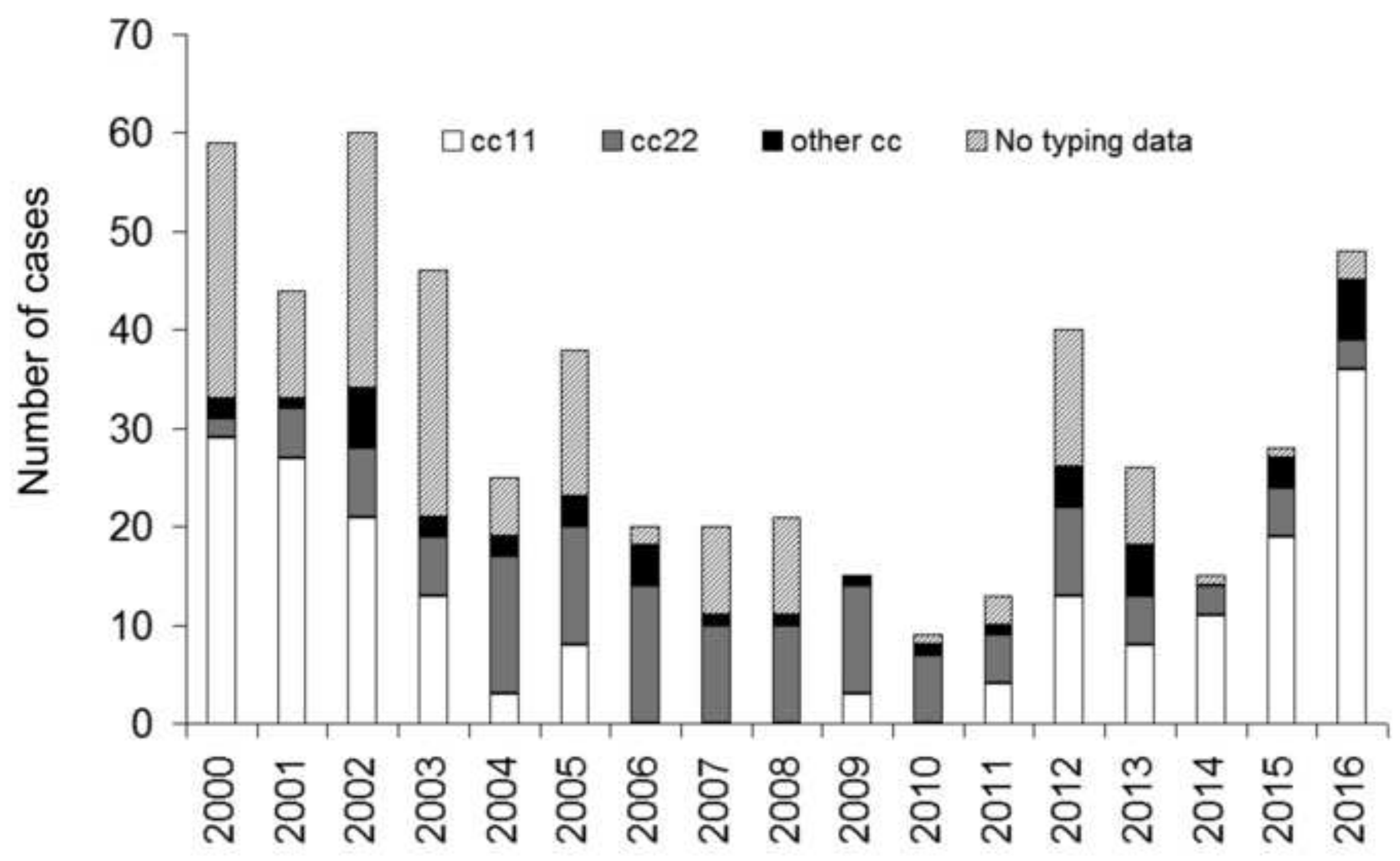




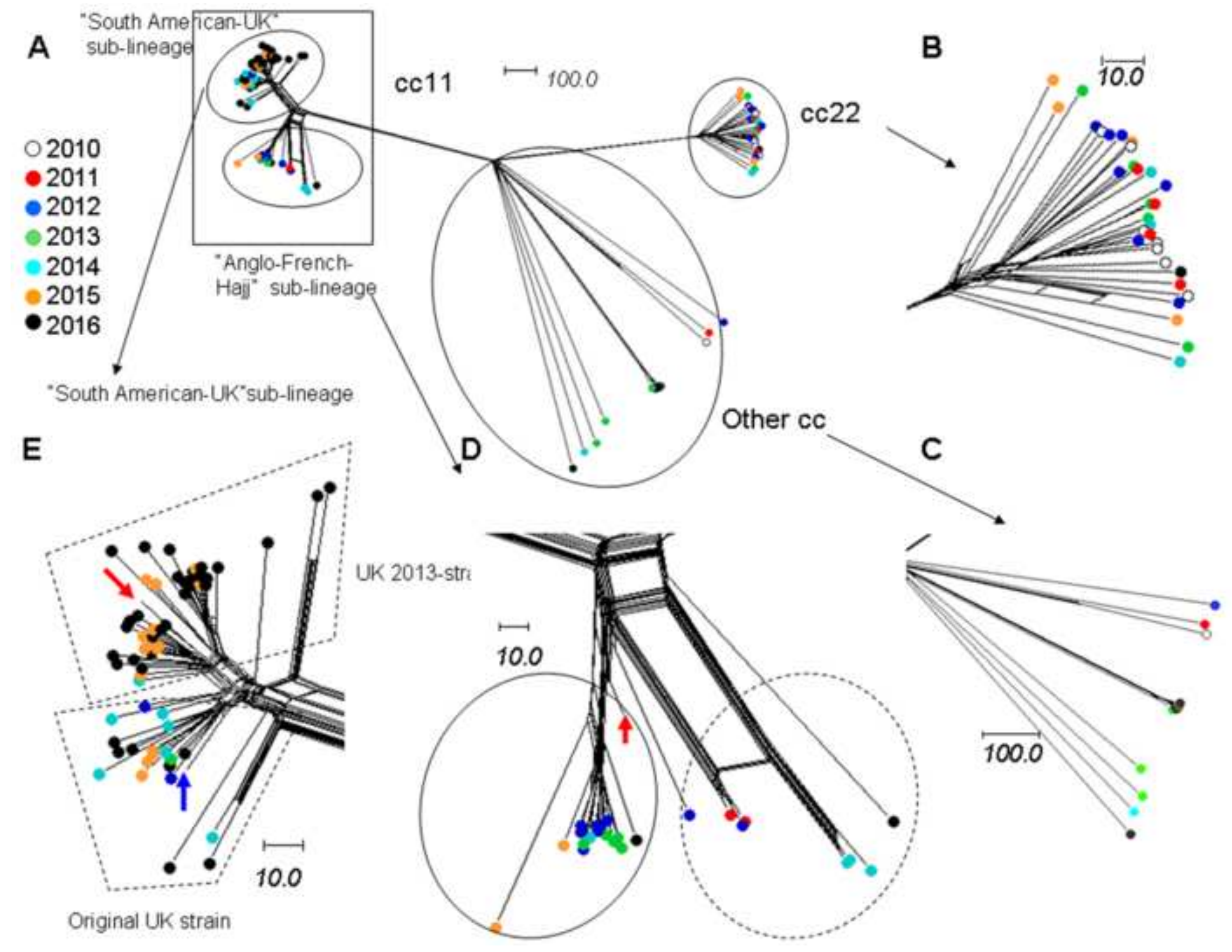




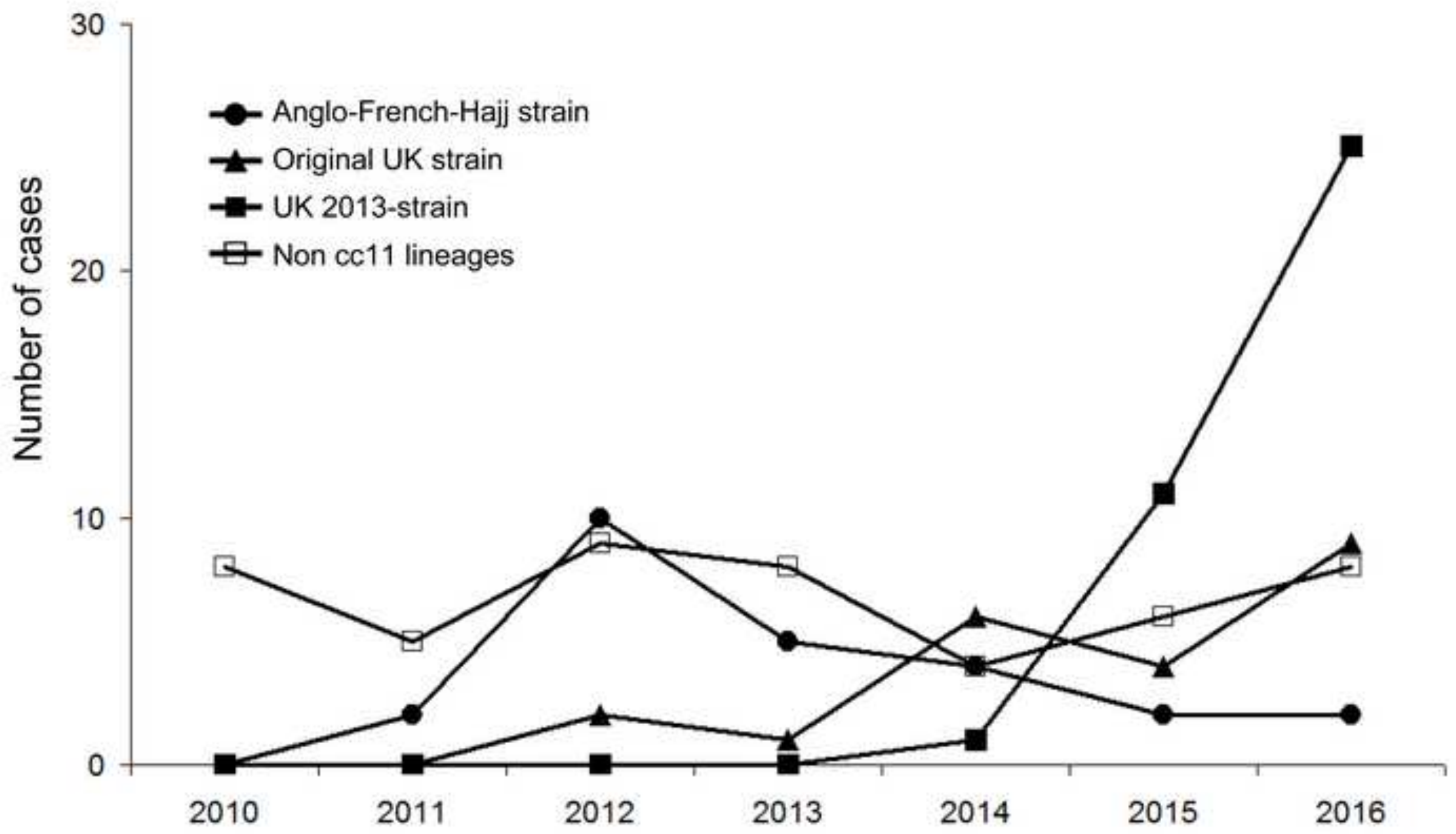




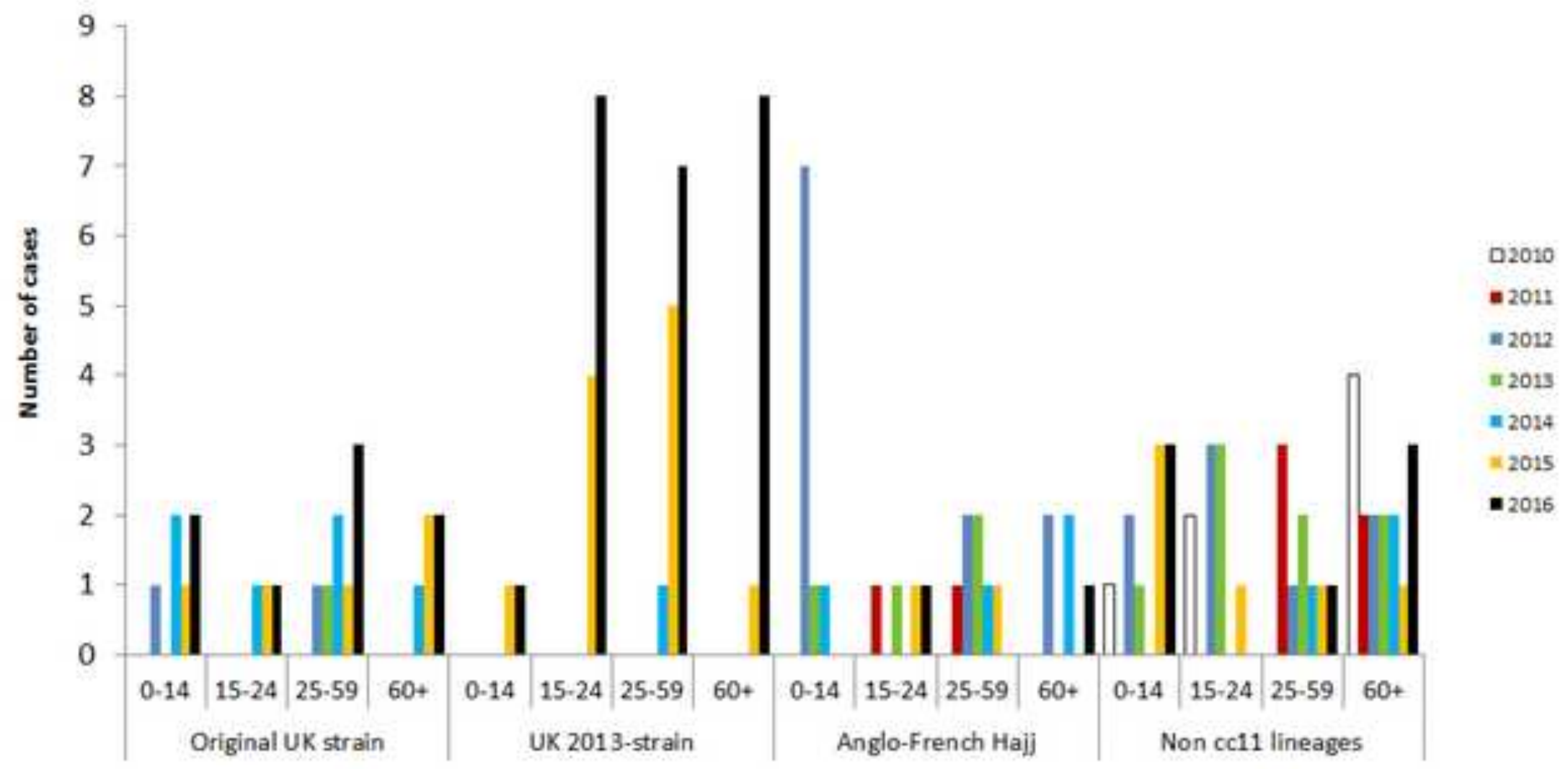


Anglo-french Hali
A Original UK strain
$\square$ UK 2013-strain
t. Non cc11 lineages
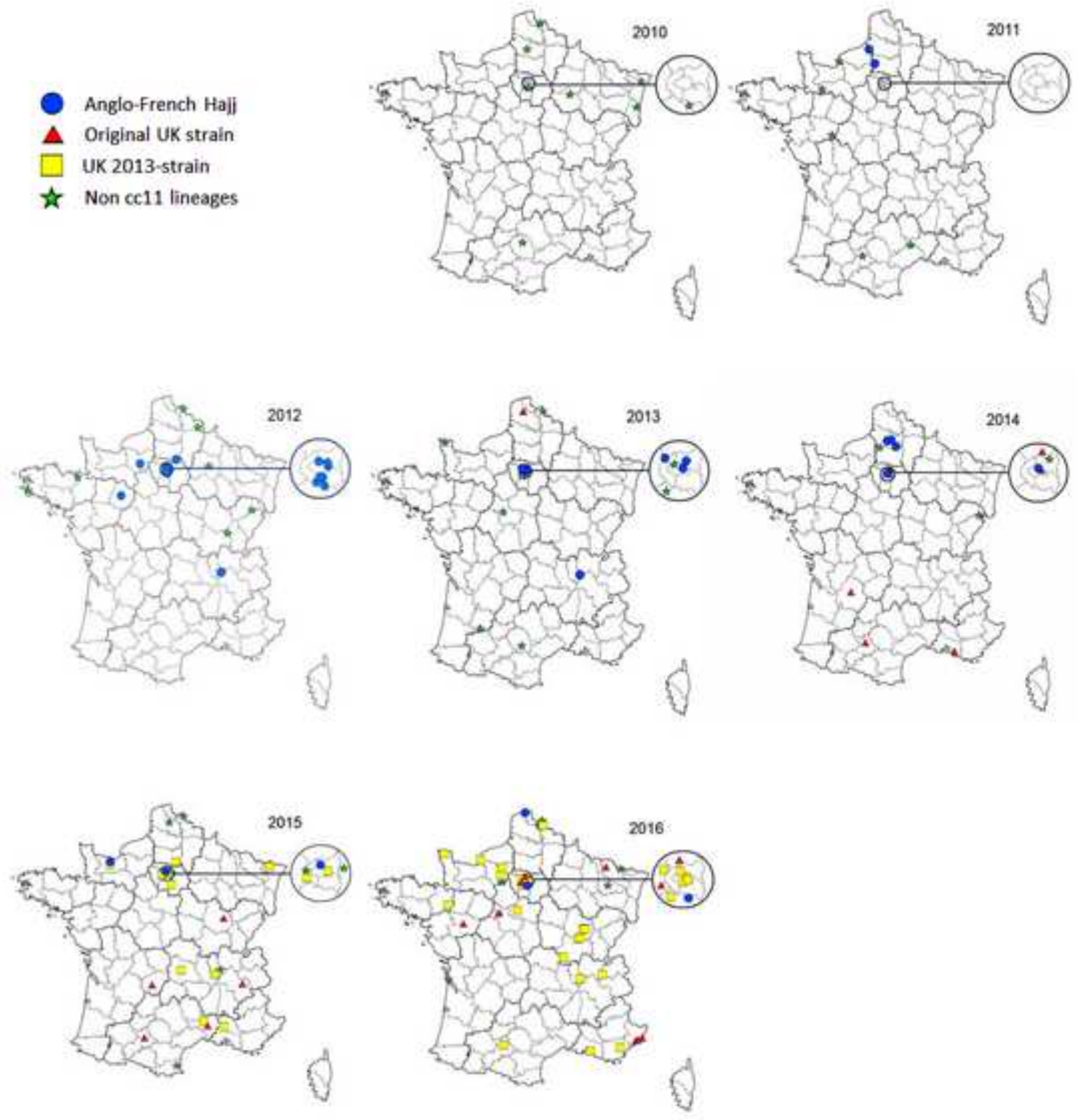
Supplementary Table
Click here to download Supplementary file: Supp_Table_id.xls

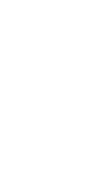

.

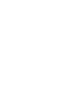

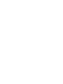

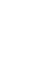

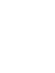

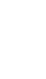

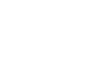

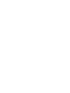

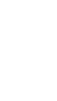
.

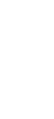

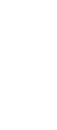

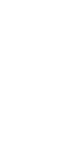

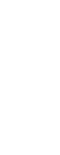

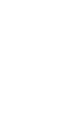

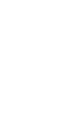
.

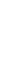
.

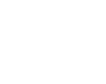
(

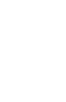

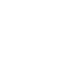

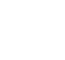

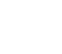

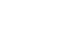

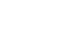

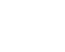

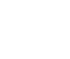

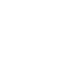

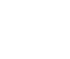

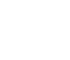

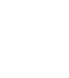

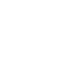

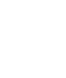

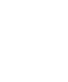

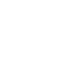

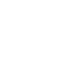

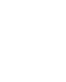

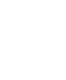
. 